\title{
超 精密加エ面のカオス特性*
}

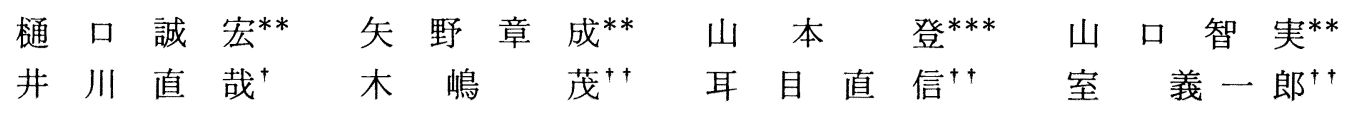

Chaotic Characteristics of Mirror-Finished Surface Produced by Ultra-Precision Turning

Masahiro HIGUCHI, Akishige YANO, Noboru YAMAMOTO, Tomomi YAMAGUCHI

Naoya IKAWA, Shigeru KIJIMA, Naonobu KENMOKU and Giichiro MURO

\begin{abstract}
Mirror-like surfaces obtained by the ultra-precision turning using diamond cutting tools are smooth to the eye, but rough under a microscope. Although a lot of work has been done on the roughness of the mirror-finished surface, its inhomogeneous static structure is not yet well analyzed. This has led to attempt to discuss quantitatively whether the surface texture was indeed chaotic or not. In the paper, the trajectory on the attractor reconstructed in phase space from a measured surface profile was characterized by the Lyapunov exponent and the correlation dimension. The characterization shows that the mirror-finished surface has the strange attractor, the positive Lyapunov exponent and the finite correlation dimension and hence it has the chaotic characteristics. Further, the mirror-finished surface produced by the ultra-precision turning becomes more chaotic as the feed rate and the cutting speed decrease.
\end{abstract}

Key words : mirror-finished surface, ultra-precision turning, chaos, attractor, Lyapunov exponent, correlation dimension

\section{1. 緒言}

単結晶ダイヤモンドエ具を用いて，磁気ディスク基板やポリ ゴンミラー,レーザ反射ミラーなどを鏡面加エする超精密切削 加工技術はすでに定着したと思われる.しかし，粗さ数十nm才 一ダの鏡面の性質については,これまでに多くの研究 ${ }^{1) \sim 4) ~ か ゙ ~}$ なされたとはいえ，いまだ十分に解明されてはいない。

鏡面は微視的に観察すると，複雑な様相を示している．とこ ろか，この複雑にみえる表面の微細構造が無秩序に形成される のか, あるいは緩やかな規則に支配されて形成されるのかは明 確になっていない，この点を明らかにするためには，まず，鏡 面の微細構造を適切なパラメ一夕を用いて評価することが必要 となる.しかし, 粗さやうねりパラメータ, ピーク密度や凹凸 平均間隔などの空間的パラメー夕, 二乗平均平方根傾斜や粗さ 面積率などの複合的パラメータ, 相対負荷面積や表面高さ分布 のひずみ度などの統計的パラメータ, パワースペクトラムなど の周波数分析パラメータなど, 一般の工学表面の評価に用いて いるパラメータ ${ }^{5)}$ で鏡面の微細構造を特徵づけたとしても, そ の形成メカニズムを推測する手掛かりが得られることは期待で きない, それ故, それに代わるものとして, 位相幾何学, 確率 統計学, 非平衡線形統計力学などの多様な学問領域と密接に関 連するカオス理論 ${ }^{6) ~-8)}$ の適用か欠欠かせないものと思われる.

以上の観点から，筆者らは超精密加工面のカオス解析を行い， 超精密加工現象のダイナミクスの軌跡として形成された加工面 の微細構造に内在するカオス性の同定と, 切削パラメータが力 オス的微細構造の形成に及ぼす影響について明らかにした。以 下に，それらについて言及する。

\section{2．実験装置と方法}

解析の対象とした鏡面は, 単結晶ダイヤモンド工具で正面切 削された磁気ディスク基板の加工面である. 磁気ディスク基板

* 原稿受付 平成 10 年 2 月 9 日

** 正 会 員 関西大学工学部 (吹田市山手町 3-3-35)

$* * *$ 関西大学工学部

†正 会 員 大阪電気通信大学工学部 (寝屋川市初町 18-8)

†† (株)ムロコーポレーション（栃木県那須郡烏山町南 1-12-25）
の表面は丸コーナ付切れ刃で荒削りされた後, 直線切れ刃で鏡 面に仕上げられた。そのとき用いた超精密旋盤と工具, また変 化させた切削パラメータの範囲は, 表 1 に示すとおりである.

鏡面の性質を精査するに当たり, 切削パラメー夕を変えて得 られる様々な加工面の工具送り方向の断面曲線(測定長さ $1 \mathrm{~mm}$ ) を, 触針式表面粗さ測定器(小坂研究所, SE-3300, 触針先端丸 み半径 $0.5 \mu \mathrm{m}$, 測定力 $0.3 \mathrm{mN}$, 最高倍率 50 万倍)を用いて測定し,

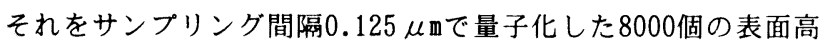
さデータを用意した。なお, 断面曲線の振幅方向の量子化の分 解能は測定倍率のフルスケールを $2^{12}$ 分割するものであった。

Table1 Cutting conditions

\begin{tabular}{|c|c|}
\hline $\begin{array}{l}\text { Machine } \\
\text { tool }\end{array}$ & $\begin{array}{l}\text { Diamond turning machine } \\
\text { (TOYADA machine works, AHP-20-25N) }\end{array}$ \\
\hline Workpiece & $\begin{array}{l}\text { Magnetic disk substrate } \\
\text { Disk size: } 3.5 \text { inch-0.8mmTH } \\
\text { Material: Al-Mg alloy A5086 (annealed) }\end{array}$ \\
\hline $\begin{array}{l}\text { Cutting } \\
\text { tools }\end{array}$ & $\begin{array}{l}\text { Finishing tool with square corner } \\
\text { Tool material: Diamond (Single crystal) } \\
\text { Tool edge angle: } 45^{\circ} \\
\text { Tool width: } 1.22 \mathrm{~mm} \\
\text { Roughing tool with rounded corner } \\
\text { Tool edge angle: } 90^{\circ} \\
\text { Corner radius: } 1.0 \mathrm{~mm}\end{array}$ \\
\hline $\begin{array}{l}\text { Cutting } \\
\text { parameters }\end{array}$ & $\begin{array}{l}\text { Cutting speed } V: 180-720 \mathrm{~m} / \mathrm{min} \\
\text { Feed rate f }: 20-80 \mu \mathrm{m} / \mathrm{rev} \\
\text { Depth of cut } t: 5-20 \mu \mathrm{m} \\
\text { Tool setting angle } \phi:-0.1-0.1^{\circ} \\
\text { Coolant: SUNCUT DT }-100\end{array}$ \\
\hline
\end{tabular}

\section{3．超精密加工面のカオス性の同定}

図 1 は超精密加エされたディスク基板表面の断面曲線群を鳥 瞰図として表した例である. 表面は粗さ $42 \mathrm{nmSRy}$ の鏡面に仕上 げられているが, 測定倍率を上げると, 不規則で複雑な微細な 構造が観察されるようになってくる．このような鏡面の性質を， 以下に述べる方法でカオス解析した。

\section{1 アトラクタとポアンカレ写像}

超精密加工面の微細構造が予測のできない確率的要因による のではなく, $d$ 個の変数で記述される力学系に支配されて形成 されるものとする. そのような場合， $d$ 次元の相空間に变数べ 
クトルの時間的な推移，いわゆるアトラク夕を描くと，特徵的 なパターンを示す．そこで，1 次元の時系列デー夕である断面 曲線を次元の異なる相空間に埋め込み, アトラクタを再構成し て，それを観察することを行った。

まず，断面曲線をサンプリング間隔 $\Delta t$ で離散化した表面高 さデー夕 $x_{1} \equiv u(i \Delta t), \quad i=1,2, \cdots, M$ から,$\tau=m \Delta t$ の時間遅れを もつ $d$ 個のデー夕をとり，それを成分とする表面高さべクトル $\overrightarrow{\mathrm{x}}_{1}=\left\{x_{i}, x_{i+1}, \cdots, x_{i+(d-1) t}\right\}$ を構成する，ベクトル $\overrightarrow{\mathrm{x}_{1}}$ は $d$ 次元相 空間上の 1 点を与えるので， $i$ を変えて $N$ 個 $(M \geqq N+d-1)$ の ベクトルを逐次，相空間に埋め込み，アトラク夕を構成する.

図 2 は，丸コーナ付切れ刃で荒削りされたディスク基板表面 の断面曲線 $(\mathrm{a})$ と, それを 3 次元相空間へ埋め込んで再構成し

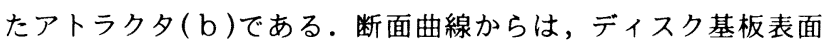
に一定ピッチの送りマークが形成されているように観察される.

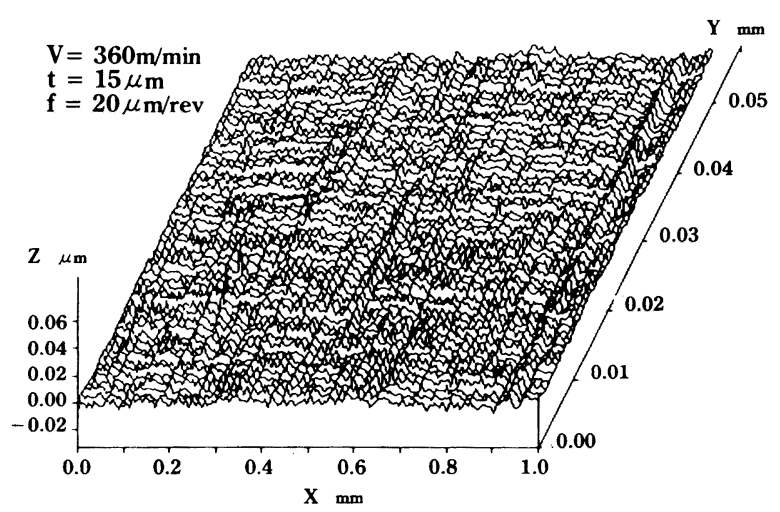

Fig.1 3-D topographical plots of a sample mirror finished surface
しかし，アトラクタを見ると， $x_{i}$ 軸まわりの軌道が $x_{i+\tau}$ 軸と $x_{i+2 t}$ 軸方向に不安定にゆらいでいる様子が認められる.そこで この相空間の $x_{i}$ 軸まわりにポアンカレ断面 $\Sigma(\Psi)$ を設け，各断 面と軌道とが交差する点群を求めると, 図 2 ( c ) のようになる これを見ると，ポアンカレ断面上で軌道の伸長や収縮が起こっ ているので, このアトラクタはカオスの特徴を内包していると 推測される.

つきに，直線切れ刃によって仕上げ削りされた表面の断面曲 線とそのアトラク夕を, 図 3 に示す. 断面曲線を見ると, 粗さ は荒削り面に比べて格段に小さくなっているが，微細な凹凸が 非周期的に形成されているのがわかる.また，3 次元相空間に 構成したアトラクタも非常に複雑な振る舞いを見せている。そ れゆえ，本アトラクタから仕上げ削り面の微細な凹凸がランダ ムであるのか, カオスであるのかを推測することができないの で, 以下に述べる方法で明らかにする。

\section{2 リアプノフ指数の解析}

超精密加工面の構造的複雑さが確率的要因に起因するのか, あるいは, 切削の力学系の不安定性によるのかは, アトラク夕 の性質を定量的に測る指標から判定される。その一つであるリ アプノフ指数はアトラクタの不安定性, すなわち表面高さべク トルの軌道がある方向に拡大し, 別の方向に縮小する様子を時 間平均した量で，以下のように定義される.

ある相空間におけるアトラクタ上の表面高さベクトル $\bar{X}_{i}$ と， それに最も近いベクトル $\overrightarrow{\mathrm{X}}_{i}$ の距離を， $a_{1}(0)=\left|\overrightarrow{\mathrm{X}}_{1}-\overrightarrow{\mathrm{X}}_{i}\right|$ とす る.また, ベクトル $\overrightarrow{\mathrm{X}}_{i}$ と $\overrightarrow{\mathrm{X}}_{i}$ から時間 $k$ 遅れたベクトル $\overrightarrow{\mathrm{X}}_{i+k}$ と $\overrightarrow{\mathrm{X}}_{i+k}$ の距離を, $a_{1}(k)=\left|\overrightarrow{\mathrm{X}}_{i+k}-\overrightarrow{\mathrm{X}}_{1+k}\right|$ とする.いま,これら の距離が指数関数的に伸長，あるいは収縮するとき，その時間 平均入はつきのように表される。

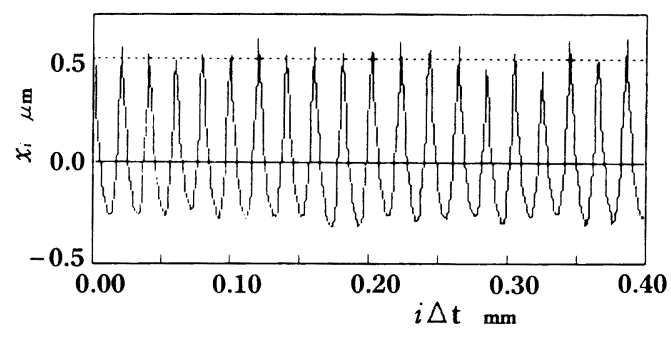

(a) Surface profile $\mathrm{V}=720 \mathrm{~m} / \mathrm{min}, \mathrm{t}=10 \mu \mathrm{m}, \mathrm{f}=20 \mu \mathrm{m} / \mathrm{rev}$

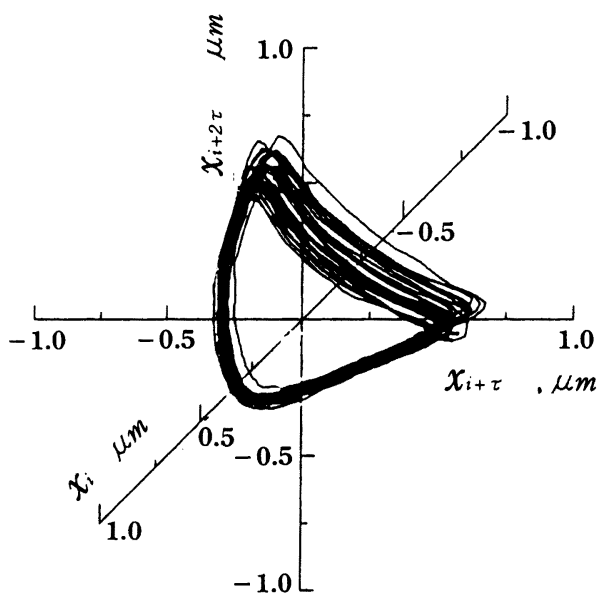

(b) Trajectry
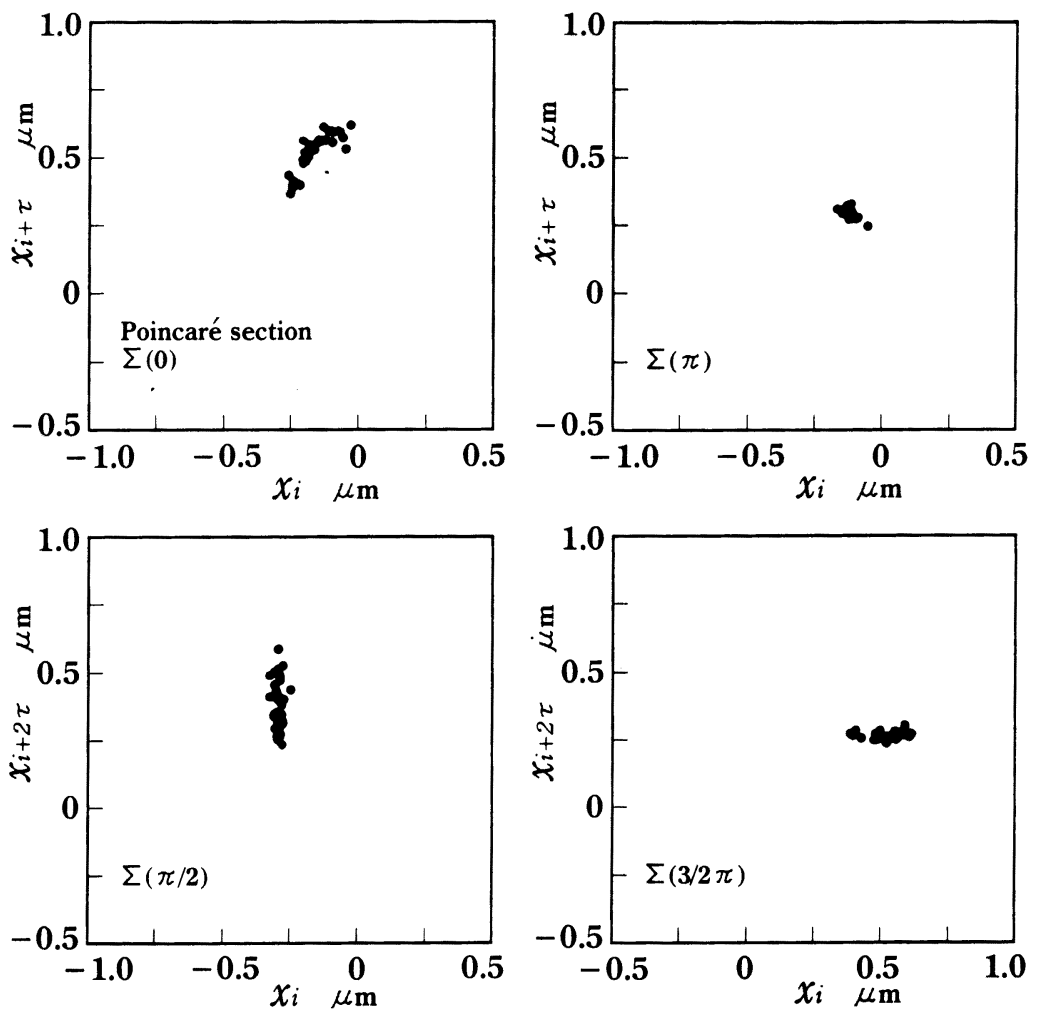

(c) Poincaré map points

Fig. 2 Surface profile for rough turned surface, its trajectory in a three dimensional state space and Poincare map points of the trajectory 


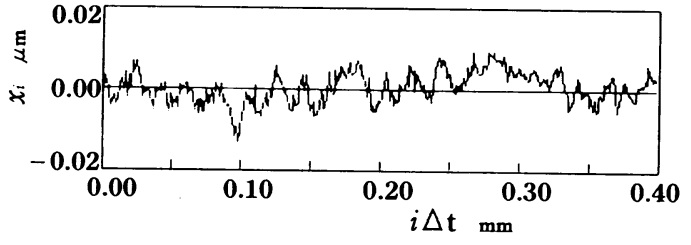

(a) Surface profile $V=720 \mathrm{~m} / \mathrm{min}, \mathrm{t}=10 \mu \mathrm{m}, \mathrm{f}=20 \mu \mathrm{m} / \mathrm{rev}$

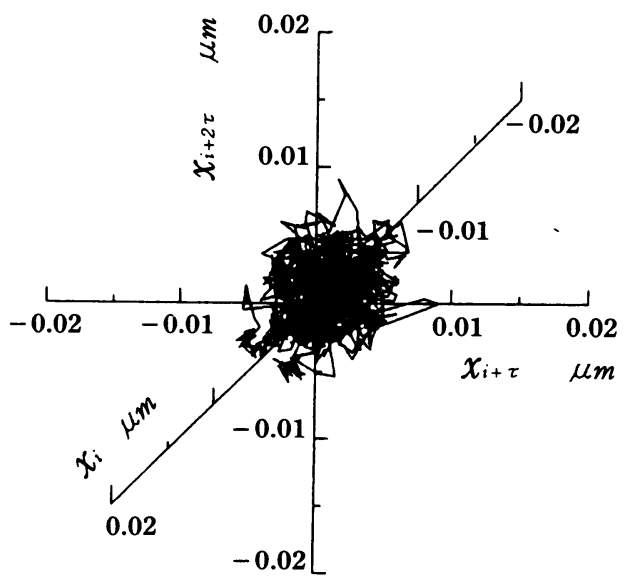

(b) Trajectry

Fig. 3 Surface profile for very fine turned surface and its trajectory in a three dimensional state space

$$
\lambda=\frac{1}{k} \log \frac{a_{1}(k)}{a_{1}(0)}
$$

ここで，入は初期値 $\overrightarrow{\mathrm{X}}_{i}$ と $\overrightarrow{\mathrm{X}}_{,}$の選び方，また遅れ $k$ の大きさに よって異なった值をとるので，幾通りかの初期值について入を 求め, それらを平均して任意性を少なくする.

$$
\lambda=\lim _{n \rightarrow \infty} \frac{1}{n k} \sum_{i=1}^{n} \log \frac{a_{i}(k)}{a_{i}(0)}
$$

ただし,$n$ はべクトル間の距離を計算する回数である.

以上のように定義されるアトラクタのリアプノフ指数を，多 次元空間の直交する各軸方向に解析し，それらを大きい順に並 ベたスペクトルを求め, つきのようにカオスの判定を行った.

リアプノフ指数入>0ならば, その方向にアトラクタの伸長 が，入<0ならば収縮が起こる.また $\lambda=0$ ならば伸縮が起こ らない.それゆえ，すべてのリアプノフ指数が正の值をもつと き,ベクトルの軌道は発散状態にあり, ランダム系であること を示す．またリアプノフ指数の少なくとも 1 つか正の值をもつ と, 軌道の伸長と収縮が起き，カオス系であることを示す．す なわち, 最大のリアプノフ指数入 $\mathrm{m}$ が正であることがカオスで あることの 1 つの条件となる。

そこで, 図 2 に示した丸コーナ付切れ刃による荒削り面と, 図 3 に示した直線切れ刃による仕上げ面の各断面曲線から構成 したアトラクタについて, 遅れ $k$ を変化させてリアプノフスペ クトルを求め, その性質を調べた。 その結果, 最大リアブノフ 指数 $\lambda_{\mathrm{m}}$ ば図 4 に示すように正の小さな值に収束し，また他の リアプノフ指数は 0 または負に収束することから，両切削面の 断面曲線はカオス性を有していると判断される。したかっって, 超精密加工面の構造的複雑さは確率的要因，いわゆるランダム な外乱によって生成されたものでなく, 切削の力学系に内在す る不安定な要因に起因するものであると考えられる.

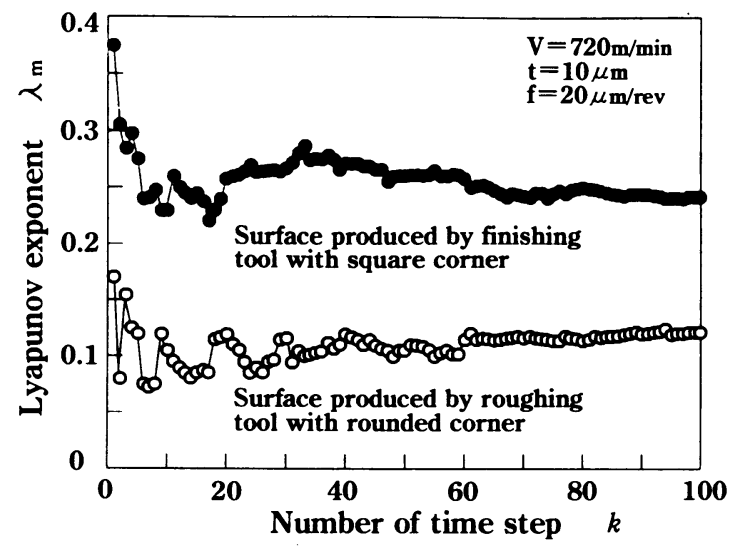

Fig. 4 Variation of Lyapunov exponent with number of time step for the surface profiles shown in Fig. 2 and Fig. 3

\section{3 相関次元の解析}

砥石作用面の断面曲線のように，特徵的な長さのない，一見 ランダムに見える図形が統計的に自己相似という性質を示すと き，図形は非整数次元のフラクタル構造をもつ。もし，不安定 な軌道を描くアトラクタがフラクタル構造をもつならば，もと の時系列データはカオスである条件の 1 つを満たす。そのため， 軌道の構造がフラクタルであるか否かを判断するために, 以下 に述べ相関次元が測定される.

いま，相空間におけるアトラクタ上の 1 つの表面高さベクト ル $\overrightarrow{\mathrm{X}}_{1}$ から, 半径 $R$ の範囲にあるベクトル $\overrightarrow{\mathrm{X}}$, の存在確率 $\Theta\left(R-\left|\vec{X}_{i}-\vec{X}_{i}\right|\right)$ を求める.これをiとiを変えて調へ，それらの 平均値を相関積分 $C(R)$ とする.

$$
C(R)=\frac{1}{N(N-1)} \sum_{i=1}^{N} \sum_{j=1}^{N} \Theta\left(R-\left|\vec{X}_{i}-\vec{X}_{j}\right|\right)
$$

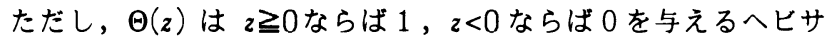
イド関数である。

つきに, 半径 $R$ を変えて相関積分 $C(R)$ を求め, 両者の間に $C(R) \propto R^{D}$ のべき乗則が成立すると，相関次元は次式のように 決定される。

$$
D_{c}=\lim _{R \rightarrow 0}\left(\frac{\log C(R)}{\log R}\right)
$$

以上のように定義される相関次元 $D_{c}$ を，いろいろな次元の相 空間の上に構成されたアトラク夕について求め, 相空間次元 $d$ に対する変化を調べる，そのとき，相空間の次元 $d$ の増大につ れて相関次元 D,が一定值に収束したならば，ランダムに見えた 時系列デー夕は有限な $D_{c}$ 次元のフラクタル構造をもつことにな る.すなわち，観測された時系列データはカオスであることの 根拠を得たことになる.

図 5 は, 図 3 の磁気ディスク基板の仕上げ面を 1 〜 次元の 相空間に埋め込んで構成したアトラクタについて, 半径 $R$ に対 する相関積分 $C(R)$ の変化を計算した結果である. 図 5 より, 相関積分 $C(R)$ は $R$ が10nmより小さい領域で, $C(R) \propto R^{D \times}$ のよ うにスケーリングされることがわかる．そこで，各グラフの傾 きから相関次元 $D$ 。を求め，それを相空間次元 $d$ に対してプロッ トしたのか，図6である.同様に，図2 の荒削り面についても 計算した相関次元 $D_{c}$ を同図に示している.

図 6 において，仕上げ面の場合，7次元より大きい相空間で， アトラクタの相関次元 $D_{c}$ が非整数の約 4.5 に収束している。一 方, 荒削り面では 3 次元以上の相空間で, 相関次元 $D$ c が約 1.3 


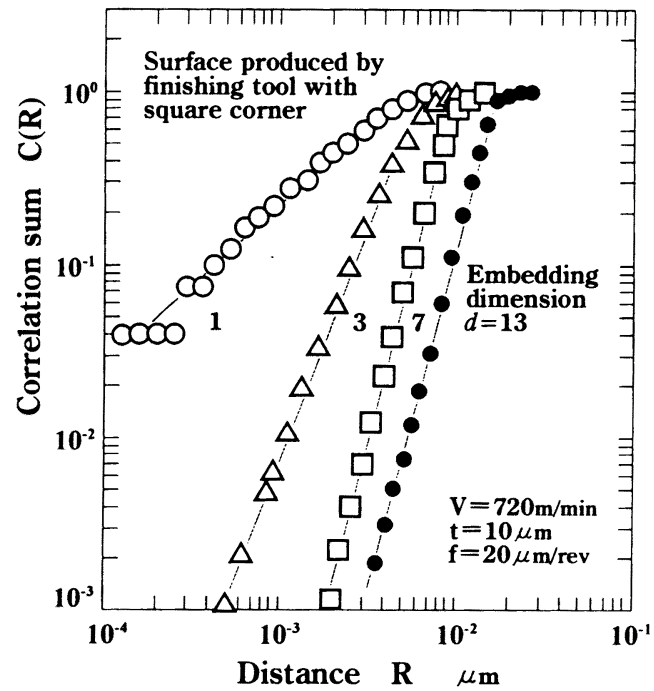

Fig.5 Plots of $\log C(R)$ as a function of $\log R$ for the surface profile shown in Fig. 3

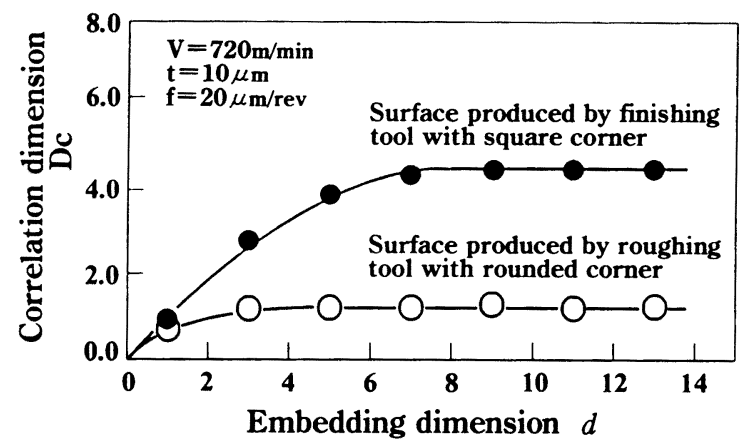

Fig. 6 Correlation dimension plotted as a function of the embedding dimension for the surface profiles shown in Fig. 2 and Fig. 3

に収束している．これより，仕上げ面と荒削り面はともにフラ クタルな性質をもち，カオスである条件を満たしている。また， 仕上げ面の方が荒削り面よりも複雑で不規則な微細構造をもつ ことが, 相関次元值の大きさからいえる.このように複雑さの 違った加工面を形成する切削の力学系は, 相関次元が一定值に 収束する相空間次元の值と同数以下の変数によって記述される。 すなわち，仕上げ面の形成には多くても 7 つの独立変数が，一 方, 荒削り面の形成には多くても3つの独立変数が関与してい ることが推定される。

\section{4. 超精密加工面のカオス特性に及ぼす 切削パラメータの影鈝}

前章で述べた解析結果より，磁気ディスク基板の超精密加工 はカオス的表面を形成することがわかった。そこで，仕上げ条 件を変えてディスク基板を加エし, 得られた様々な鏡面をリア プノフ指数と相関次元で特徵づけて，鏡面のカオス特性に及ほ す切削パラメータの影響について調べた。

前田 ${ }^{112)}$ は, 工具設定角を変えると鏡面の粗さが異なるこ とを報告しているので，まず工具設定角の影響について検討し た. 図 7 に仕上げ面の粗さ $R_{y}$ と工具設定角 $\phi$ の関係を示す。こ こでいう工具設定角は, 直線切れ刃ダイヤモンド工具の前切れ 刃が被削面に対してなす角をさす。
図 7 より，工具設定角 $\varnothing$ 正または負にとると，基本的に， 切削方向に垂直な面内の横, 前切れ刃稜の転写が行われる. し かし, 仕上げ面の鳥瞰図から明らかなように, 工具設定角 $\phi か ゙$ 正の場合, 横切れ刃による切削作用に付随して, Al合金に含ま れる晶出物や介在物に起因すると言われているむしれやひっか き傷のため, 粗さは大きくなっている.また, 工具設定角 $\phi か ゙$ 負の場合, 送りマークの稜線部分にバリが発生して, やはり粗 さは大きくなっている.

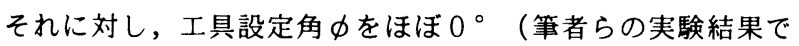
は約 $\left.0.02^{\circ}\right)$ にすると, 前切れ刃稜によるバニシング作用によ って, 粗さの小さな鏡面が形成される.なお,このバニシング 作用は圧縮残留応力を発生させ ${ }^{9)}$, その大きさは微小部 X 線応 力測定装置 (理学電機製, PSPC/RSF) を用いた筆者らの測定で は, 約 $50 \mathrm{MPa}$ 程度であった。

さて, 工具設定角 $\varnothing か ゙$ 仕上げ面のリアプノフ指数入 $\mathrm{m}$ と相関 次元 $D_{c}$ に及ぼす影響は, 図 8 のように示される. 図より, 工具

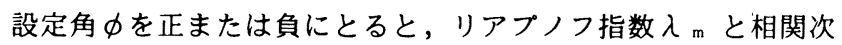
元 $D_{c}$ は小さくなり, 工具設定角 $\phi$ をほほ $0^{\circ}$ にしたとき, それ
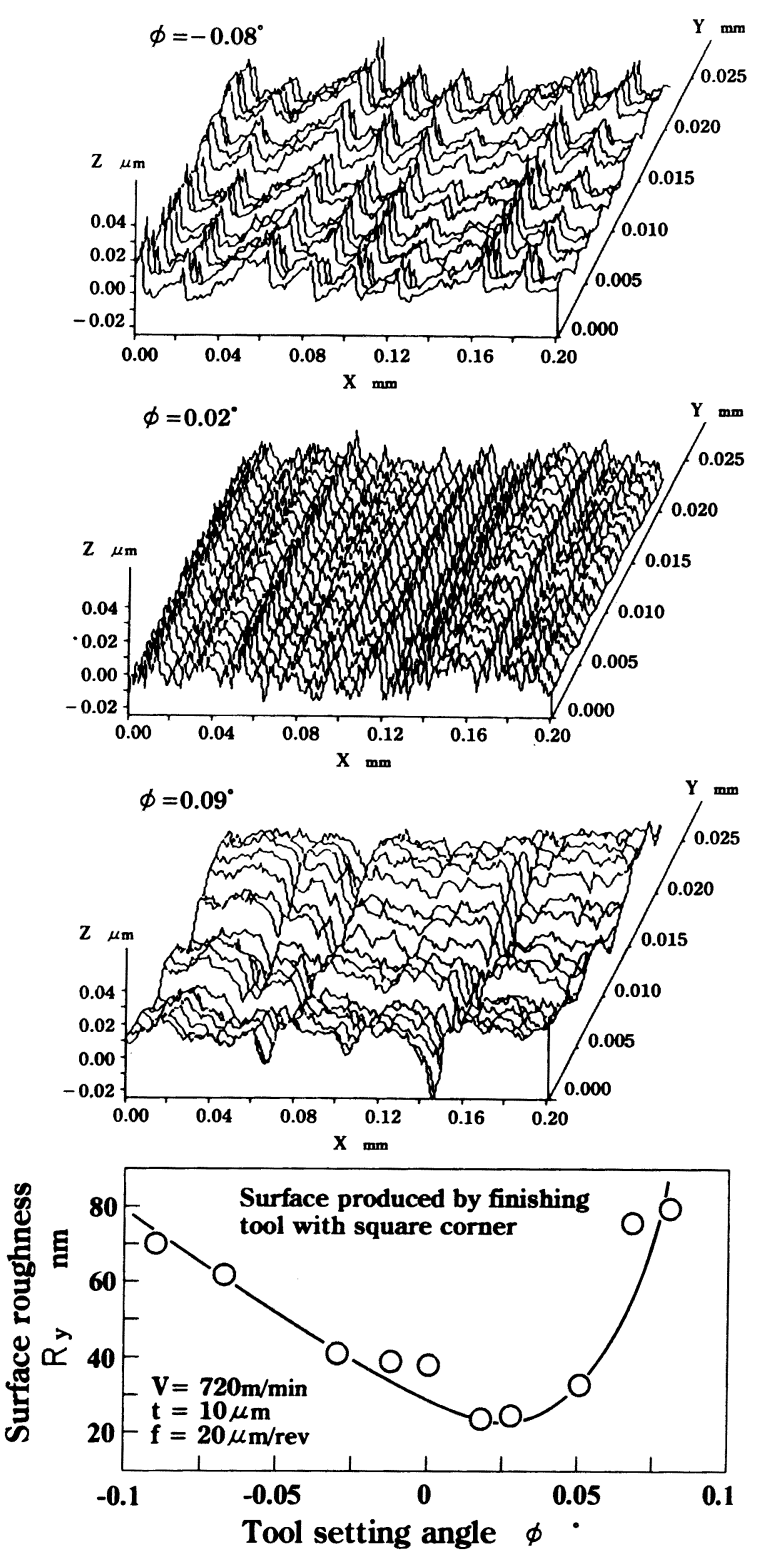

Fig.7 Influence of tool setting angle on surface roughness 


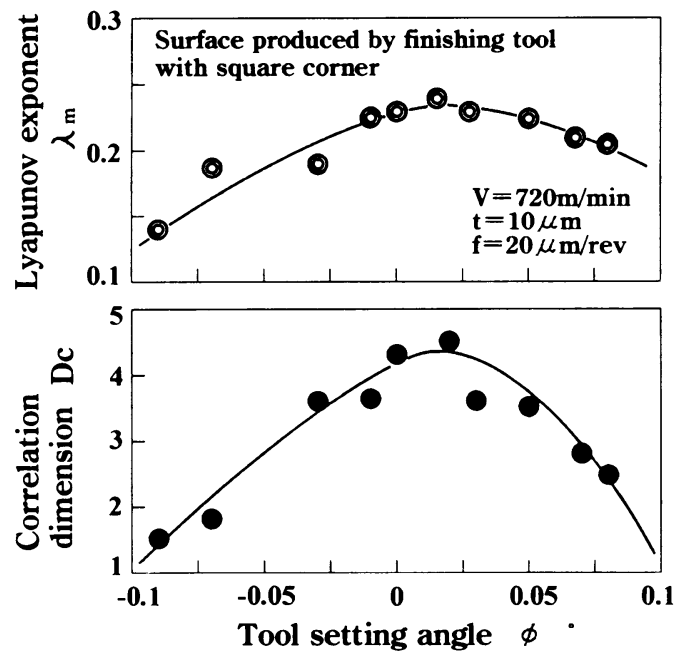

Fig. 8 Variation of Lyapunov exponent and correlation dimension with tool setting angle
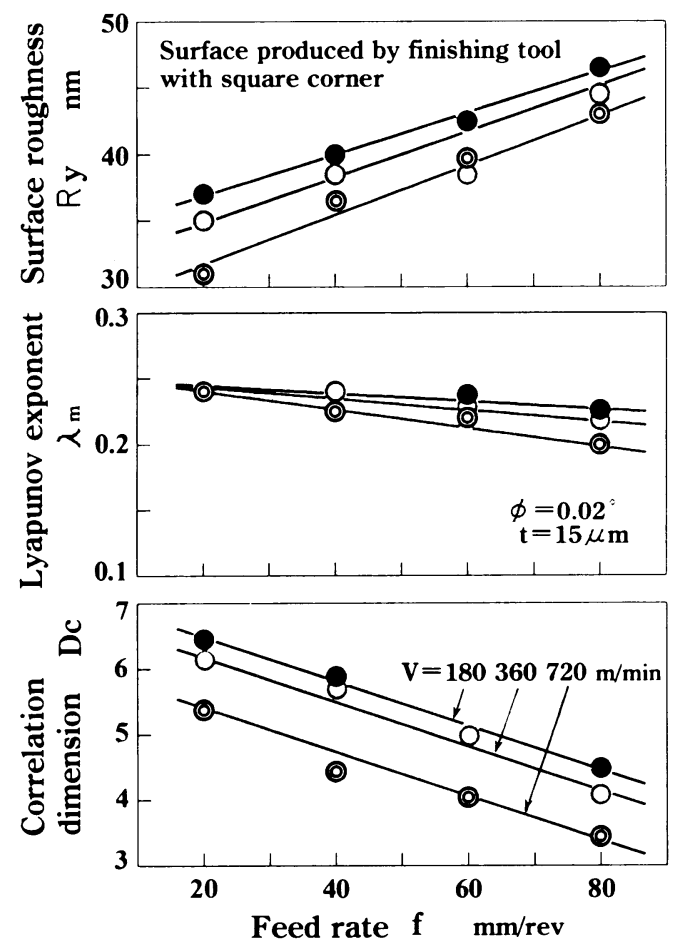

Fig. 9 Variation of surface roughness, Lyapunov exponent and correlation dimension with feed rate and cutting speed

らは最も大きくなるのがわかる．この結果は, 工具設定角 $\phi \fallingdotseq$ $0^{\circ}$ の下に形成される仕上げ面の相空間におけるアトラクタが, 特に, 指数的にある方向に大きく発展して, 別の方向に縮小す る複雑なフラクタル図形の様相を呈していることを定量的に表 現している.つまり，元の仕上げ面が周期性の崩れた微細な凹 凸形状の幾何学的複雑性をもっていることを示唆している。こ のような解釈の妥当性は, 図 7 に示した仕上げ面の鳥瞰図を見 れば明らかである。したがって，微細な構造をもつ粗さの小さ な仕上げ面を得るには，工具設定角を約 0 ○にすることが必要 となるが，その切削機構はバニシング作用を伴うため, 多くの パラメータに影響される複雑なものであると推察される.

つきに，仕上げ削り条件が仕上げ面のカオス特性に及ぼす影 響を, 図 9 に示す．仕上げ面の粗さ $R_{y}$ は送り速度 $f$ が低いほど,
また切削速度 $V$ が速いほど小さくなる．しかし，リアプノフ指 数 $\lambda_{\mathrm{m}}$ と相関次元 $D_{c}$ は送り速度 $f$ と切削速度 $V$ が共に小さいほ ど大きくなる．これは低送り，高切削速度領域ほどバニッシ効 果が大きいためであると考えられる.

以上のように, 単結晶ダイヤモンド工具を用いた超精密加工 では, 工具設定角, 送り速度, 切削速度が鏡面の微細構造の形 成に影響することが明らかになった。しかし，前述の相関次元 の解析結果は, 仕上げ面形成に最大 7 つのパラメータが関与す ることを示唆しているので，鏡面のカオス性に影響する未知の パラメータをさらに明らかにしたいと考えている。

\section{5. 結論}

超精密加土された磁気ディスク基板表面の断面曲線からアト ラク夕を再構成し, そのポアンカレ写像, リアプノフ指数, 相 関次元を解析した結果, 以下の結論が得られた。

(1) アトラクタの最大リアプノフ指数が正の小さな值を示し, また相関次元が非整数の一定值に収束したので，磁気ディ スク基板表面はカオスの性質を示す。

（2）直線切れ刃による仕上げ削り面は丸コーナ付切れ刃によ る荒削り面に比べてリアプノフ指数と相関次元の大きい高 次元カオスの特徴を示す.

（3）直線切れ刃工具の設定角をほぼ $0^{\circ}$ にするとき，リアプ ノフ指数と相関次元の大きい微細構造をもつ鏡面が形成さ れる。

（4）低送り速度，低切削速度領域において，リアプノフ指数 と相関次元の大きい高次元カオスの特徵をもつ鏡面が生成 される.

以上のことから, 超精密加工面の構造的複雑さは切削の力学 系に内在する不安定な要因に起因するものであると考えられる.

\section{謝辞}

本研究は平成 9 年度関西大学重点領域研究助成のもとに行わ れたことを記し，謝意を表します。

$$
\text { 参 考 文 献 }
$$

1) 前田幸男, 桝田正美, 西口 隆, 沢 真司, 伊藤 立：ダイヤモ ンドエ具によるAl合金の鏡面切削に関する研究(第 1 報)一バイト 設定角の切削面粗さへの影響一，精密工学会誌， $54 ， 10$ ，(1988） 1993.

2）前田幸男, 桝田正美, 西口 隆, 沢真司, 伊藤 立: ダイヤモ ンド工具によるAl合金の鏡面切削に関する研究(第 2 報)一摩耗バ イトによる切削面形成メカニスムー, 精密工学会誌, 55,5 , (1989) 847.

3）半澤一哉, 江田 弘, 貴志浩三, 上野秀雄: 超精密切削加工に関 する研究一磁気ディスクサフストレートの加エー, 精密工学会誌, $53,4,(1987) 571$.

4）菅野 健，竹内喜代松，吉田嘉太郎：Al合金の鏡面加エについて (第 2 報，工具摩耗と表面性状），日本機械学会論文集 C 編，57, 536, (1991) 1346 .

5）柳 和久：磁気記録媒体における表面凹凸のキャラクタリゼーシ ヨン, 精密工学会誌, $61,11,(1995) 1516$.

6）長谷川素由, 劉建成: 旋削・研削加工面の表面キャラクタリゼー ション, 精密工学会誌, 61, 11, (1995) 1537.

7) R.C.Hilborn: Chaos and Nonlinear Dynamics, Oxford University Press, (1994).

8) 山本 登: 非線形数学入門, 関西大学出版部, (1997).

9）菅野 健，竹内喜代松，後藤崇之，吉田嘉太郎：Al合金の鏡面加 エについて，日本機械学会論文集 C編，53，485，(1987） 222. 